\title{
References:
}

1. Kokun O.M., Agayev N.A., Pishko I.O., Lozinskaya N.S., Kornya L.V. Psychological assessment of suicide risk in servicemen. Methodical manual. Kyiv, 2019. 206 p.

2. Sergeenkova OP. Age psychology Kyiv: Center for Educational Literature, 2012. $376 \mathrm{p}$.

3. World Health Organization: http://www.who.int/countries/ukr/en/

DOI https://doi.org/10.30525/978-9934-588-80-8-1.31

\section{READYNESS OF FUTURE SPECIALISTS FOR SELF-EDUCATION ACTIVITY}

\section{Chernihivska N. S.}

Candidate of Pedagogic Sciences, Associate Professor, Head of the Department of Romance and Germanic Languages

National Academy of the Security Service of Ukraine

\section{Ivasyshyna T. A.}

Candidate of Philological Sciences, Associate Professor, Head of the Department of Eastern and European Languages

National Academy of the Security Service of Ukraine

\section{Vinnytska T. M.}

Senior teacher at the Department of Romance and Germanic Languages National Academy of the Security Service of Ukraine

$$
\text { Kyiv, Ukraine }
$$

The aim of the work is to demonstrate the need to form the future professionals' readiness for self-education activities, to form the desire of life-long learning, to emphasis the importance of teachers' psychological and pedagogical skills while formation the conative component of readiness for self-education.

The processes of modernization the higher education in Ukraine have necessitated the development of a new generation of professionals ready for life-long learning. The normative legal documents (Laws of Ukraine «On Higher Education», «On Innovative Activity») clearly outlined the tendencies of educational processes development, which required future specialists to be able to accomplish knowledge throughout life-long learning, what meant to be ready for motivated self-education activity. 
Based on the research of V. Stelnikov, we believe that the higher education applicants, future specialists, should have a developed conative sphere and the need for self-education activity to realize their potential. In our opinion, the formation of the future specialists readiness for selfeducation activity can take place under the following conditions: involvement the higher education applicant in the process of independent search and new knowledge acquisition, problem-solving; understanding by the applicant the importance and expediency of a particular subject studying; complex, but feasible training; constant checking and evaluation of the applicant's work (transparency and the clarity of evaluation, provided by the rating system of higher education applicants' achievements evaluation), enthusiasm of the teacher's devotion to his subject and educational material $[6$, c. 156].

Compliance with these conditions increases the motivation for selfeducation activity. The distance learning with the help of distance learning courses is rather deployed. We agree with the S. Sysoeva opinion that a mature personality with a correspondingly formed level of motivation, ability to work, self-organization and self-control can study at a distance form [5, c. 85]. We believe that different factors can be as motivation: economic (desire for economic independence), moral (satisfaction of their own ambitions, desire to expand their range of vision, the need for independent creative activity), social (authority in a particular social group) etc., so the question of motivating future professionals to self-education activity are the basis for addressing the issue of readiness for these activities.

Taking into account the results of scientific research by V. Vilyunas, O. Leontiev, A. Markova, A. Maslow, which include the motive of activity, specific actions and operations, control and analysis of the achieved results, we note that a full-cycle of activity is not possible without the usage of methods of stimulation and motivation, organization, control and selfcontrol. Thus, we consider the presence of motivation of the future specialist activity as the element of his readiness for self-education activity.

Based on the research of N. Sidorchuk, we distinguish the following groups of methods for forming the self-education activity of the future specialist:

- methods of motivation and stimulation the self-education activity;

- methods of self-education activity development;

- methods of control, mutual control and self-control [4, c. 218].

Developing the criterion base of readiness for the self-education activity, we turned to the existing psychological criteria, indicators and their levels, proposed in the scientific works of G. Lindsay, V. Molyako, I. KurkulenkoLukyanets. Based on the scientists' researches, we believe the psychological 
criteria include: the level of satisfaction (realized by attitude to the ultimate goal of learning - the future profession obtaining); the level of educational motivation (acquires significance of the applicant's attitude to the process of the goal advancing). Self-education activity of the individual is understood as a qualitative aspect of activity in terms of vocational training and can be revealed by the following criteria: professional orientation and learning motivation. Based on the above, we think that motivation is the basis for the formation of self-educational activities readiness of the future specialist and life-long learning maintenance.

To reveal the essence of motivation, we turn to the scientific research of A. Markova (motivation of person activity is the basis and direction of human activity) [1, c. 192], R. Nemova (the more a person has different motives, needs and goals, the more developed his motivational sphere is) [3, c. 688], D. Uznadze (perspective unexplored model of future activity, with the prediction of its end result «casual» and «comprehensive») [7, c. 451]. O. Leontiev (motives that motivate the activity, give it a «personal meaning», have the same determination as any mental reflection, so they could be controlled). Based on the continuity and interrelation of needs and motives, we found that the high motivational mood of the applicants ensures the disclosure of the educational and cognitive activities purpose. The motivational aspect of formation the self-education activity readiness involves the organization of motivational and cognitive activity and the formation of self-education activity motives.

The analysis of psychological, pedagogical and philosophical sources allowed us to conclude that in the «motive - need» connection the motivation of human activity is primary. A. Maslow connected selfobservation, which was considered as a process, with the motivation of development [2, c. 307]. Based on the psychologist's earmarked two types of motivation: overcoming the deficit, which he considered as a motivational list that helped a person meet the needs of five levels (biological, security and confidence in the future, self-esteem, self-realization) and commitment to development (motivation of being), we think that the motivation of the applicant for higher education actions, future specialist, to self-education activity could be the state of new deficit elimination, or knowledge, skills and abilities improvement.

Thus, the psychological basis of the process of the motivational component the future specialist's readiness for self-education forming became contradictions between professional tasks (the need to constantly improve their skills and abilities, to perform tasks quickly and efficiently, to improve their qualification, to master and improve skills of new information technologies, to master foreign language and constantly increase the level of 120 
its proficiency, to be competitive, etc.) and low level of professional knowledge and skills, in particular in the self-education activity organization acquired in the process of training in the higher educational establishment. Formation of motivational and cognitive activity of the future specialist and motives of self-education activity forming is not only growth of positive or negative attitude to the profession, but gradual complication of motives system, establishment of new relations between them as a result of contradictions overcoming. The state of self-education activity motivation should be changed from a dynamic constant to a stable constant.

The process of motivation forming during the pedagogical interaction of teachers and the higher education applicants consists in the selective actualization of certain higher level needs, which under the condition of systematic activation gradually turn into stable motivational personality states and qualities. The teacher professional and psychological-pedagogical knowledge, his usage in the training process the problem-searching, game, dialogic, creative, project personality-oriented technologies, which during the systematic activation the curiosity and the need for new knowledge, creating the lesson intellectual background, gradually turn into stable personality motivation states and qualities.

Thus, we can conclude that the task of a higher educational establishment teacher is to determine the system of motives necessary for self-education activity, to evoke them in higher education applicants during specially organized activities, to ensure the awareness and consolidation of existing motives in further professional activities. This approach will provide an opportunity to form the readiness of the future specialist for self-education activity and the stable understanding of the need for life-long learning.

\section{Література:}

1. Маркова А. К. Психология труда учителя. Москва : Просвещение, 1993. 192 с.

2. Маслоу А. Психология быта: пер. с англ. Москва : Рефлбу; Ваклер, 1997. $307 \mathrm{c.}$

3. Немов Р. С. Психология: в 3-х кн. : учеб. для студ. высш. пед. учеб. заведений. 5-е изд. Москва : ВЛАДОС, 2008. Кн. 1. Общие основы психологии. $687 \mathrm{c.}$

4. Сидорчук Н. Г. Організація самоосвітньої діяльності майбутніх учителів у процесі вивчення предметів педагогічного циклу : дис. ... канд. пед. наук : 13.00.04. Житомир, 2001. 218 с.

5. Сисоєва С. О. Проблеми дистанційного навчання: педагогічний аспект. Неперервна професійна освіта: теорія і практика. Педагогіка. Психологія. 2003. Вип. 3/4. С. 78-87. 
6. Стельніков В. Ю. Педагогічні основи забезпечення особистісного і професійного розвитку студентів засобами інноваційних технологій навчання. Полтава : РВВ ПУСКУ, 2002. Кн. 1. С. 151-156.

7. Узнадзе Д. Н. Психологические проблемы мотивации поведения человека. Москва : Просвещение, 1969. 122 с.

DOI https://doi.org/10.30525/978-9934-588-80-8-1.32

\title{
ПСИХОЛОГІЧНІ ОСОБЛИВОСТІ ПРОЯВУ ЕМОЦІЙНОГО ІНТЕЛЕКТУ УЧНЯМИ-ЛІДЕРАМИ
}

\author{
Чернобай I. B. \\ практичний психолог \\ Криворізька загальноосвітня школа № 19, \\ центр розвитку особистості «ПізнавайКА» \\ м. Кривий Ріг, Дніпропетровська область, Украӥна
}

Мета роботи: виявити та узагальнити специфіку прояву емоційного інтелекту учнів-лідерів шкільного самоврядування.

Емпіричною гіпотезою дослідження $є$ припущення про те, що в учнів-лідерів учнівського самоврядування показники емоційного інтелекту вище, ніж в учнів, що не займають лідерських позицій.

Емоційний інтелект (EMOTIONAL QUALITY), як предмет соціальнопсихологічного дослідження в останні десятиліття став широко розповсюдженим феноменом. Концепція емоційного інтелекту згідно положення про Нову Українську школу є вагомим аспектом під час освітнього процесу.

Вперше термін «Емоційний інтелект» в психології ввели Д. Майер і П. Саловей (Salovey, Mayer, 1990), які і стали засновниками концепції емоційного інтелекту. Але найбільш ранні коріння досліджень EQ простежуються ще в роботах Чарльза Дарвіна. У 1940 році Д. Векслер описав вплив не розумових факторів на інтелектуальну поведінку. В 1983 році Г. Гарднер в роботі «Рамки розуму: теорія множинного інтелекту» висунув припущення про множинні інтелекти, окремо розглядаючи міжособистісний інтелект (здатність розуміти наміри, мотиви і бажання інших людей) і внутрішньо-особистісний інтелект (здатність зрозуміти себе, оцінити свої почуття, страхи і мотиви). На думку Г. Гарднера, традиційні показники інтелекту, такі як IQ, не в 